\title{
Isolation, Production, and Characterization of Protease from Bacillus subtilis IB No. 11
}

\author{
Min Hyang Lee*, Kang Moon Lee**, Yong Jin Choi* and Yeon Soo Baek* \\ Inno Bio Co., LTD., Korea*, Korea Polytechnic University**
}

\begin{abstract}
A potent protein degrading bacterium was isolated from soil samples of different environments. Polyphasic taxonomic studies and phylogenetic 16S rRNA sequence analyses led to identify the isolate IB No. 11 as a strain of Bacillus subtilis. The isolated strain was recognized to produce protease constitutively, and the maximum production $(1.64 \mathrm{units} / \mathrm{ml})$ was attained in a shake flask culture when the isolate was grown at $40^{\circ} \mathrm{C}$, for $32 \mathrm{~h}$ in basal medium supplemented with starch $(0.25 \%)$ and gelatin $(1.25 \%)$ as sole carbon and nitrogen source, respectively. The optimum $\mathrm{pH}$ and temperature for the protease activity were determined to be $\mathrm{pH} 7.0$ and $50^{\circ} \mathrm{C}$, respectively. $\mathrm{Ca}^{2+}$ and $\mathrm{Mn}^{2+}$ enhanced remarkably the protease activity but neither showed positive effect on the protease's thermal stability. In addition, it was observed that the protease was fairly stable in the $\mathrm{pH}$ range of 6.5-8.0 and at temperatures below $50^{\circ} \mathrm{C}$, and it could be a good candidate for an animal feed additive. The inhibition profile of the protease by various inhibitors indicated that the enzyme is a member of serine-proteases. A combination of UV irradiation and NTG mutagenesis allowed to develop a protease hyper-producing mutant strain coded as IB No. 11-4. This mutant strain produced approximately 3.23 -fold higher protease activity $(6.74$ units $/ \mathrm{mg})$ than the parent strain IB No. 11 when grown at $40^{\circ} \mathrm{C}$ for $32 \mathrm{~h}$ in the production medium. The protease production profile of the selected mutants was also confirmed by the zymography analysis.
\end{abstract}

(Key words : Protease, Bacillus subtilis IB No. 11, Isolation, Characterization)

\section{INTRODUCTION}

Proteases (EC.3.4.21-24 \& 99) are a complex group of enzymes collectively known as peptidyl-peptide hydrolases. They are responsible for the hydrolysis of peptide bonds in a protein molecule by the process of proteolysis, and are ubiquitous in occurrence, being found in all living organisms $(1,10)$.

They constitute one of the most important groups of industrial enzymes, accounting for $40 \sim 60 \%$ of the world total enzyme sales with more than two thirds of the proteases commercially produced from microbial origin (18).

Recently, proteases have attracted renewed interest, mainly due to the recognition that they not only play an important role in the cellular metabolic processes but have also gained considerable attention in the industrial community (1).

Today, the enzymes have become widely used in various industrial sectors, such as detergent, food, pharmaceutical, leather, diagnostics, waste management, and silver recovery (19).

The potential uses of proteases and the need for development of economical processes for the highly active enzyme production still continue to stimulate the search for new microbial strains capable of producing higher levels of proteases with novel catalytic properties.

The data presented here describe the isolation and identification of a bacterial strain producing a high level of protease having the potential for using as an animal feed additive and/or an efficient proteolytic enzyme for the hydrolysis of soy protein. Also described in this report are factors that affect the production of the enzyme by the isolate, some properties of the enzyme activity, and the isolation of protease hyper-producing mutants of the $B$. subtilis IB No. 11strain.

\section{MATERIALS AND METHODS}

\section{Organism and taxonomic study}

A protease overproducing bacterial strain was isolated from soil samples of different environments collected mostly in Kyunggi

Corresponding author: Y. J. Choi, Inno Bio Co., LTD. 1Ra 103, Shiwha Industrial Complex, 1236-2 Jungwang-dong, Shiheung-shi, Gyeonggi-do, KOREA. Tel: +82-31-432-0002, Fax: +82-31-432-0009, E-mail: yjchoi-kk@hanmail.net 
prefecture by selective screening on the selective substrate agar plates. The selective plate contained the following: $0.1 \mathrm{M}$ $\mathrm{Na}_{2} \mathrm{HPO}_{4}, 0.05 \mathrm{M} \mathrm{KH}_{2} \mathrm{PO}_{4}, 0.1 \mathrm{mM} \mathrm{CaCl}_{2}, 0.1 \mathrm{mM} \mathrm{MgSO}_{4}, 0.8 \%$ Casein, $0.1 \%$ glucose, and $1.5 \%$ agar.

The soil samples collected were suspended in sterile $0.85 \%$ saline, and heat-treated at $95^{\circ} \mathrm{C}$ for $10 \mathrm{~min}$. The heat-treated and appropriately diluted cell suspensions were spread on the selective agar plates. After 2 days incubation at $40^{\circ} \mathrm{C}$, the plates were observed for clear zones around the colonies.

The isolated bacterium was identified by following the standard protocols described in Bergey's Manual of Systemic Bacteriology (11). Further, 16S rRNA sequence analysis and construction of phylogenetic tree by neighbor joining method (20) were also conducted for confirming the identity of the isolated IB No. 11 to species level.

\section{Culture medium and growth conditions}

The basal medium for shake flask cultures contained (per liter) the following: $\mathrm{NaH}_{2} \mathrm{PO}_{4}, 4 \mathrm{~g} ; \mathrm{K}_{2} \mathrm{HPO}_{4}, 8 \mathrm{~g} ; \mathrm{NH}_{4} \mathrm{Cl}, 1.0 \mathrm{~g} ; \mathrm{CaCl}_{2}$, $0.5 \mathrm{~g} ; \mathrm{MgSO}_{4} \cdot 7 \mathrm{H}_{2} \mathrm{O}, 0.05 \mathrm{~g} ; \mathrm{MnSO}_{4} \cdot 2 \mathrm{H}_{2} \mathrm{O}, 0.02 \mathrm{~g} ; \mathrm{FeSO}_{4}$, $0.001 \mathrm{~g}$; glucose, $0.02 \mathrm{~g}$, and casein, $0.08 \mathrm{~g}$ (pH 7.0).

Cultivations were carried out on a gyratory shaker $(150 \mathrm{rpm})$ for $30 \mathrm{~h}$ at $40^{\circ} \mathrm{C}$ in $100 \mathrm{ml}$ Erlenmeyer flasks with a working volume of $25 \mathrm{ml}$. The cultures were centrifuged at $8000 \mathrm{rpm}$ for $10 \mathrm{~min}$, and the cell-free supernatant thus obtained was used as the crude enzyme solution for estimation of proteolytic activity.

\section{Mutagenesis}

To obtain protease hyper-producing mutants, the isolated strain IB No. 11 was cultured at $40^{\circ} \mathrm{C}$ in the basal medium described above until the optical density at $600 \mathrm{~nm}$ was around 1.0. The bacterial cells harvested by centrifugation were washed twice with sterile saline, and then irradiated under UV light for $4 \mathrm{~min}$ in a Petri dish. This irradiation resulted in a suitably low survival rate (1.0-0.1\%). After the exposure, $0.1 \mathrm{ml}$ aliquots of the cell suspension were spread onto the selective calcium casein agars supplemented with 2-deoxyglucose $(2 \mathrm{mg} / \mathrm{ml})$ and nisin $(0.15$ $\mathrm{mg} / \mathrm{ml})$. The bacterial colonies which had formed a clear-zone around them in $24 \mathrm{~h}$ incubation at $40^{\circ} \mathrm{C}$ in the dark were selected and their protease activity was determined according to the assay method described below.
The mutant strain showing the highest protease activity was selected and subsequently subjected to N-methyl-N'nitro-Nnitrosoguanidine (NTG) mutagenesis. The cell suspension of the mutant selected as described above was treated with $0.5 \mathrm{mg} / \mathrm{ml}$ NTG for $30 \mathrm{~min}$ at $50^{\circ} \mathrm{C}$ with a resultant $90 \%$ drop in viability. After the NTG treatment, the cells were collected by centrifugation at $4^{\circ} \mathrm{C}$ and $5000 \mathrm{rpm}$, and washed twice with sterile saline. Then, the appropriately diluted cells were spread onto the selective media supplemented with 2-deoxyglucose $(2 \mathrm{mg} / \mathrm{ml})$ and $\operatorname{nisin}(0.2 \mathrm{mg} / \mathrm{ml})$, and the mutant strains obtained from the selective plates were screened by using the same method described above.

\section{Enzyme assay}

Protease activity was measured according tothe method of Cupp-Enyard C. (5) using casein as a substrate. Briefly, a $1.0 \mathrm{ml}$ aliquot of the enzyme solution was mixed with $5.0 \mathrm{ml}$ of $50 \mathrm{mM}$ potassium phosphate buffer $(\mathrm{pH} 7.5)$ containing $0.65 \%$ casein, and incubated at $37^{\circ} \mathrm{C}$ for 10 minutes.

The reaction was stopped by addition of $5 \mathrm{ml}$ of $110 \mathrm{mM}$ trichloroacetic acid (TCA) solution. Subsequently, the reaction mixture was allowed to stand at room temperature for $30 \mathrm{~min}$, and then centrifuged at $10,000 \mathrm{~g}$ for $10 \mathrm{~min}$ to remove the precipitate.

A blank was conducted in the same manner, except that $1.0 \mathrm{ml}$ of the enzyme solution was added after addition of the TCA reagent.

To $2.0 \mathrm{ml}$ of the supernatant thus obtained, $5 \mathrm{ml}$ of a $500 \mathrm{mM}$ sodium carbonate solution was added, and immediately afterwards $1 \mathrm{ml}$ of Folin's reagent was added. After incubating the mixture at $37^{\circ} \mathrm{C}$ for $30 \mathrm{~min}$, the absorbance was measured at $660 \mathrm{~nm}$.

A standard curve was generated using solutions of 0-0.553 $\mu \mathrm{M}$ tyrosine. One unit of protease activity was defined as the amount of enzyme required to liberate $1 \mu \mathrm{g}$ tyrosine per min under the same experimental conditions described above.

\section{Protein determination}

The soluble protein content of crude enzyme solutions was estimated by Bradford's method (3) with crystalline bovine serum albumin $(1 \mathrm{mg} / \mathrm{ml})$ used as a standard protein. 
6. Effect of $\mathrm{pH}$ and temperature on the activity and stability of the enzyme

The optimum $\mathrm{pH}$ of the protease was studied over the $\mathrm{pH}$ range of 5.0-9.0 using different buffers of varying $\mathrm{pH}$ values. For the study of $\mathrm{pH}$ stability, the enzyme solution was incubated for 30 min at $50^{\circ} \mathrm{C}$ in different buffers and then, the residual proteolytic activity was measured under the standard assay conditions.

The following buffer systems were used: $1.0 \mathrm{M}$ acetate buffer, $\mathrm{pH}$ 5.0-6.5; $1.0 \mathrm{M}$ phosphate buffer, $\mathrm{pH}$ 6.5-7.5, and Tris- $\mathrm{HCl}$ buffer, $\mathrm{pH}$ 7.5-9.0.

To examine the effect of temperature, the protease activity was determined at different temperatures between 30 and $60^{\circ} \mathrm{C}$ at $\mathrm{pH}$ 6.5. Thermal stability was tested by incubating the enzyme at 40 , 50 , and $60^{\circ} \mathrm{C}$ for $15 \mathrm{~min}$. Aliquots were withdrawn at appropriate time intervals to determine the remaining protease activity at $\mathrm{pH} 6.5$. The original enzyme activity before incubation was taken as $100 \%$.

\section{Effect of inhibitors and metal ions on the pro- tease activity}

Effects of enzyme inhibitors on the protease activity were examined using phenylmethylsulfonyl fluoride (PMSF), ethylenediaminetetraacetic acid (EDTA), o-phenanthroline, iodoacetate, and pepstatin. The proteolytic activity was measured in the presence of the inhibitors at several different concentrations under the standard assay conditions.

The activity of the enzyme assayed in the absence of inhibitor was taken as $100 \%$.

The influence of various metal ions on the enzyme activity was investigated by adding the divalent metal ions to the reaction mixture at various concentrations $(1.0 \mathrm{mM}, 5.0 \mathrm{mM}$ or $10 \mathrm{mM})$. The activity of the protease in the absence of metallic ion was taken as $100 \%$.

\section{Zymography}

Zymographic assays were performed as described by Sissons et al. (21) with some minor modifications. Ten percent polyacrylamide gels were copolymerized with $0.075 \%$ gelatin. Samples were dissolved in nonreducing Laemmli sample buffer without heat denaturation and run at $100 \mathrm{~V}$. Following electrophoresis, the gels were washed for $60 \mathrm{~min}$ in $50 \mathrm{mM}$ Tris-
$\mathrm{HCl}$ buffer (pH 7.5) containing 2.5\% Triton X-100, with gentle agitation, in order to remove the excess of sodium dodecyl sulfate (SDS). Then, the gels were incubated for an additional $6 \mathrm{~h}$ with several changes of the solution of $50 \mathrm{mM}$ Tris- $\mathrm{HCl}(\mathrm{pH} 7.5)$ contained $0.2 \mathrm{M} \mathrm{NaCl}$ and $5 \mathrm{mM} \mathrm{CaCl}$. Zones of proteolysis were observed by overnight Coomassie blue staining.

In another experiment, samples were pretreated with $5 \mathrm{mM}$ inhibitors indicated above for $30 \mathrm{~min}$ at $37^{\circ} \mathrm{C}$. The inhibitors were also included in the loading buffer at the same final concentration.

\section{RESULTS AND DISCUSSION}

\section{Isolation and identification of the microorganism}

During the initial screening course for isolation of protease overproducing microorganisms with emphasis on thermophilic bacteria, 7 bacterial colonies exhibiting large halos of casein degradation around their colony on the selective plates were isolated from 86 soil samples of different environments which had preheat-treated as described in Materials and Methods.

After purification through repeated streaking on the fresh selective medium, the individual isolates were screened for production of proteolytic activity in shake flask cultures. Among the 7 isolates described above, the strain coded as IB No. 11 was finally selected for further studies as it produced the highest extracellular protease activity $(0.29$ units $/ \mathrm{ml})$ when grown in the basal medium at $40^{\circ} \mathrm{C}$ for $30 \mathrm{~h}$.

The isolate IB No. 11 was observed under the microscope to be a motile, gram-positive, rod-shaped, and endospore forming bacterium.

The comparative analysis of the morphological characteristics and the physiological properties of the isolate, including catalaseand oxidative-positive properties with the valid criteria recorded in the Bergey's manual of systemic bacteriology suggested that the strain IB No. 11 belongs to the genus Bacillus. For further classification of the isolate to species level, phylogenetic sequence analyses were performed using the $16 \mathrm{~S}$ rRNA gene sequence (1083 bp) determined in this work.

The Blast search using the complete 16S rRNA gene sequence as a query against the GenBank data base and Ribosomal Data base project library showed that the rRNA sequence of the strain IB No. 11 was found to have $98.6 \%$ identity with that of Bacillus subtilis X2. 
Further, phylogenetic analyses were performed using the NEIGHBOUR program (http://rdp.cme. msu. edu/) and the fourth version of Molecular Evolutionary Genetics Analysis (MEGA) software (http:// www.megasoftware.net)on the basis of the entire sequence data of the 16S rRNA gene of the isolate.

As illustrated in Fig. 1, the phylogenetic tree derived from the $\mathrm{NJ}$ analysis revealed that the isolate could be affiliated to a typical gram-positive bacterium Bacillus subtilis which led to the identification of the strain IB No. 11 as a strain of the species of $B$. subtilis.
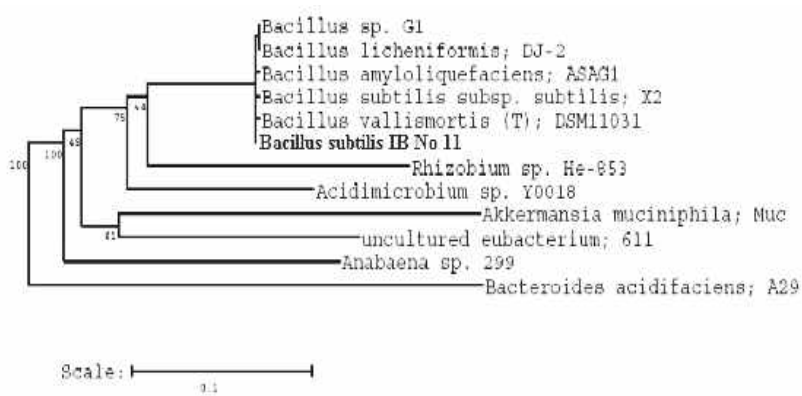

Fig. 1. Phylogram from the neighbour-joining analysis of the strain IB No. 11.

The numbers associated with the branches refer to bootstrap values resulting from 500 replicate samplings with the bootstrap values higher than $45 \%$ being shown.

\section{Protease production in shake flask cultures}

\section{(1) Effect of carbon sources on the protease production}

Carbon and nitrogen sources play crucial roles in cell growth and enzyme synthesis by microorganisms. Therefore, to analyze the influence of carbon source in the basal medium on protease secretion, the strain IB No. 11 was grown at $40^{\circ} \mathrm{C}$ for $30 \mathrm{~h}$ in the basal medium supplemented with a sole carbon source of several different compounds at the concentration of $0.5 \%$.

As seen in Table 1, the strain IB No. 11 grew well in all media tested but the highest protease titre estimated by the specific activity $(0.77 \mathrm{U} / \mathrm{mg}$ of protein) was achieved with starch. Intriguingly, glucose and xylose also favored high protease production. Whereas, fructose and sucrose were, unexpectedly, found to repress synthesis of the protease. Similar results of catabolite repression from studies on the influence of readily metabolizable carbon sources on protease production were reported earlier where the microorganisms were grown in synthetic media supplemented with glucose as a sole carbon source $(7,14$, and 17).
Table 1. Protease production by the isolate IB No. 11 in various carbon sources

\begin{tabular}{cccc}
\hline \multirow{2}{*}{ C-source } & Biomass & \multicolumn{2}{c}{ Enzyme production } \\
\cline { 3 - 4 } & (OD at 600nm) & $\begin{array}{c}\text { Activity } \\
(\mathrm{U} / \mathrm{ml})\end{array}$ & $\begin{array}{c}\text { Specific activity } \\
(\mathrm{U} / \mathrm{mg})\end{array}$ \\
\hline \hline Glucose & 1.08 & 0.53 & 0.73 \\
Fructose & 1.32 & 0.33 & 0.37 \\
Galactose & 2.59 & 1.03 & 0.54 \\
Glycerol & 1.74 & 0.58 & 0.47 \\
Xylose & 2.12 & 1.00 & 0.65 \\
Lactose & 1.99 & 0.88 & 0.61 \\
Sucrose & 1.72 & 0.47 & 0.38 \\
Maltose & 1.73 & 0.69 & 0.56 \\
Starch & 1.44 & 0.77 & 0.77 \\
\hline
\end{tabular}

The strain IB No. 11 was grown at $40^{\circ} \mathrm{C}$ in the basal medium containing each carbon source at $0.5 \%$, and protease yield was determined after $30 \mathrm{~h}$ cultivation.

Of note, glucose showed, as described above, no repression of the protease production up to $2.0 \%$, although the cell growth of the strain continued to increase without further increase in the enzyme activity (Data not shown).

Next, influence of the concentrations of starch in the basal medium on the production of proteolytic activity was examined in this optimization experiment. The maximum protease was produced in the presence of $0.25 \%$ starch, and at higher concentrations, the protease production was gradually decreased although the growth was still observed (Fig. 2).

\section{(2) Effect of $\mathrm{N}$-source on the protease production}

In general, microbial proteases are known to be constitutive (12) or partially inducible enzymes (9). Organic nitrogen sources such as casamino acid (2), casein (7), and yeast extract (15) are well known inducers of protease production.

In addition, they are crucial components of the medium for higher production of microbial enzymes.

Hence, the influence of various organic nitrogen sources on the protease production by the present strain IB No. 11 was investigated using the basal medium supplemented with a nitrogen source indicated in Table 2 at the concentration of $0.5 \%$.

As shown in the table, the highest protease activity was attained when the strain was grown in the basal medium supplemented with gelatin as a nitrogen source.

Particularly, the strain IB No. 11 produced a significant level of 


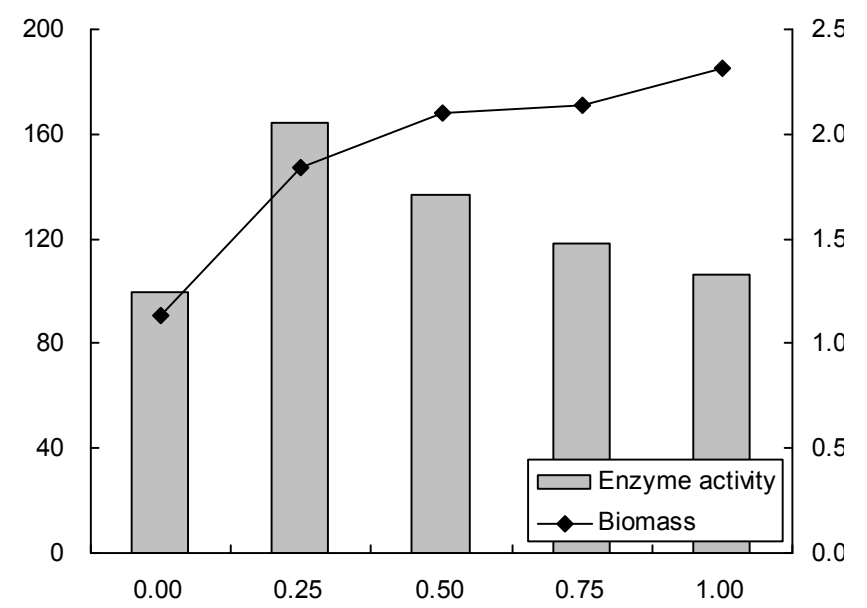

Fig. 2. Effect of starch concentrations on the protease production.

Cells were grown in the basal medium containing various concentrations of starch as a sole carbon source at $50^{\circ} \mathrm{C}$ and for $30 \mathrm{~h}$.

Table 2. Effect of organic nitrogen sources on the protease production

\begin{tabular}{cccc}
\hline \multirow{2}{*}{ N-source } & $\begin{array}{c}\text { Biomass } \\
\text { (OD at 600nm) }\end{array}$ & $\begin{array}{c}\text { Enzyme production } \\
\text { Activity } \\
\text { (U/ml) }\end{array}$ & $\begin{array}{c}\text { Specific activity } \\
\text { (U/mg) }\end{array}$ \\
\hline \hline Control & 0.23 & 0.03 & 0.29 \\
Casein & 0.37 & 0.09 & 0.41 \\
Casamino acids & 0.29 & 0.01 & 0.08 \\
Corn steep solids & 1.35 & 0.65 & 0.65 \\
Gelatin & 0.56 & 0.62 & 1.64 \\
Peptone & 1.13 & 0.74 & 0.89 \\
Skim milk & 0.37 & 0.03 & 0.13 \\
Soybean meal & 1.44 & 0.70 & 0.65 \\
Yeast extract & 0.54 & 0.39 & 1.09 \\
Urea & 0.29 & 0.01 & 0.05 \\
\hline
\end{tabular}

Cultivation was carried out in conical flasks with the $30 \mathrm{ml}$ basal medium supplemented with the nitrogen source indicated in the table at $0.5 \%$.

The biomass and protease activity were determined after $30 \mathrm{~h}$ of cultivation.

protease $(0.14 \mathrm{U} / \mathrm{mg}$ of protein) in the absence of any organic nitrogen supplement, implying that the enzyme was constitutively synthesized in this strain. Whereas, there was a remarkable decrease in the protease production when some organic nitrogen compounds such as urea, casamino acid, and skim milk were added as a nitrogen source.

Interestingly, ammonium chloride, one of the most readily metabolizable nitrogen compound was found to greatly favor the production of protease, being a contrast to the findings reported previously $(13,14,22)$.

Subsequently, the optimum concentration of gelatin for the protease production was determined where starch was used as a sole carbon source added at $0.25 \%$.

The best concentration of gelatin was determined to be around $1.25 \%$, indicating that the optimum $\mathrm{C} / \mathrm{N}$ ratio for the enzyme production is $16.7 / 83.3$ (Fig. 3).

On the other hand, as seen in the figure, the cell growth was observed to continue still at the gelatin concentrations up to $2.0 \%$ tested in this study.

Next, the time course of the protease production in the shake flask culture was examined under the culture conditions optimal for the enzyme formation by the strain IB No. 11.

As depicted in Fig. 4, the maximum cell growth was attained in $12 \mathrm{~h}$ cultivation while the protease synthesis was detected initially in the culture broth after $9 \mathrm{~h}$ cultivation. Thereafter, the production of protease was sharply enhanced with culture time, and reached the highest level of 0.36 units $/ \mathrm{ml}$ after $30 \mathrm{~h}$ of cultivation.

On the other hand, the $\mathrm{pH}$ value of culture fluid was observed to be fairly stable without the growth-associated drop of $\mathrm{pH}$, and this is possibly due to the high phosphate buffer concentration.

\section{Effect of $\mathrm{pH}$ and temperature on protease activity and stability}

\section{(1) Influence of $\mathrm{pH}$}

The $\mathrm{pH}$ activity profile of the protease was determined using 3 different buffers of varying $\mathrm{pH}$ values as described in Materials

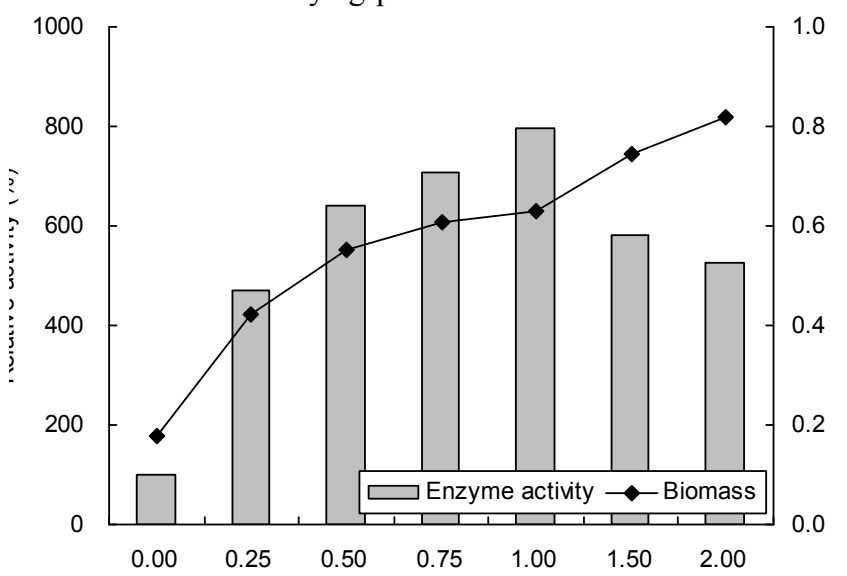

Fig. 3. Determination of the optimal concentration of gelatin for the protease production. 


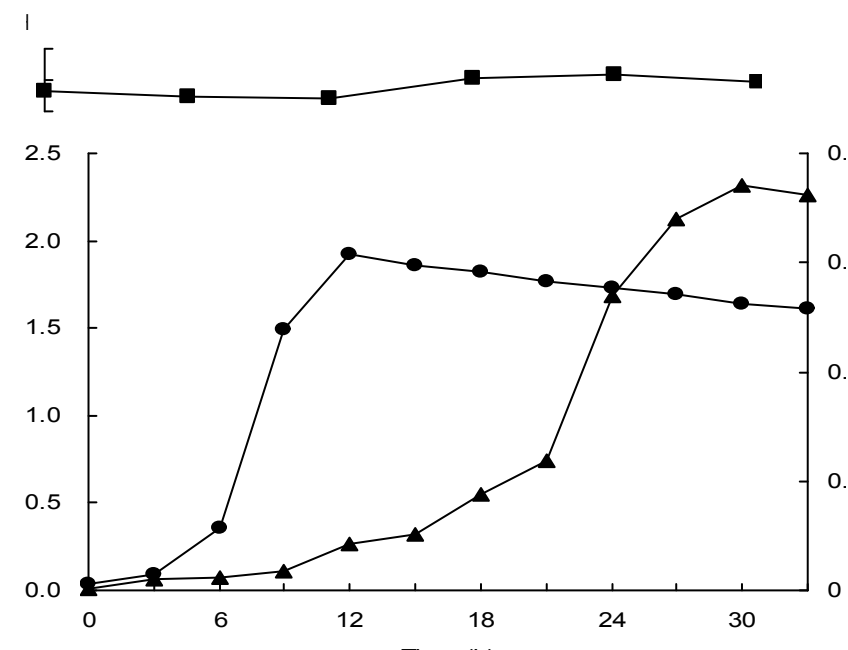

Fig. 4. Time course of the protease production by the isolate IB No. 11.

Cultivation was done at $40^{\circ} \mathrm{C}$ for $35 \mathrm{~h}$ in the production medium.

and Methods. As illustrated in Fig. 5a, the protease was found to be active in the $\mathrm{pH}$ range of 6.5-8.0 with an optimum $\mathrm{pH}$ around 7.0. These results indicated that the protease produced by the strain IB No. 11 could be classified into a neutral group of protease (10).

In addition, the enzyme was stable over the $\mathrm{pH}$ range of 5.0-7.5 maintaining $100 \%$ of its originalactivity after $30 \mathrm{~min}$ incubation at each $\mathrm{pH}$ value and $50^{\circ} \mathrm{C}$ (Fig. $5 \mathrm{~b}$ ). These $\mathrm{pH}$ activity and stability profiles suggested that the protease has the potential for application in feed industry.

\section{(2) Effect of temperature}

The effect of temperature on the IB No. 11 protease activity was examined at $\mathrm{pH} 6.5$ and various temperatures indicated in Fig. 6a. The protease was demonstrated to be highly active between 40 and $60^{\circ} \mathrm{C}$ with an optimum temperature of $50^{\circ} \mathrm{C}$ as shown in Fig. 6a.

The thermal stability test of the protease showed that it was fairly stable at temperatures below $50^{\circ} \mathrm{C}$ after 15 min incubation but inactivated rapidly at higher temperatures than $50^{\circ} \mathrm{C}$, indicating that this protease could be used only under mild heating conditions (Fig. 6b).

\section{Effect of inhibitors and metal ions on the enzyme activity}

In order to determine the nature of the protease produced by the

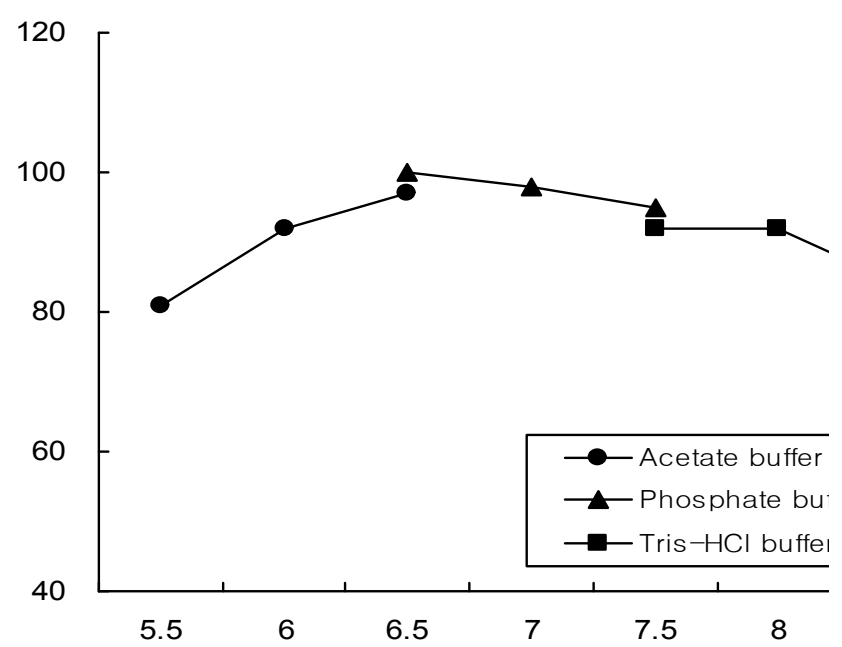

Fig. 5a. pH dependency of the protease activity.

The maximum activity obtained at $\mathrm{pH} 6.5$ was considered as $100 \%$ activity.

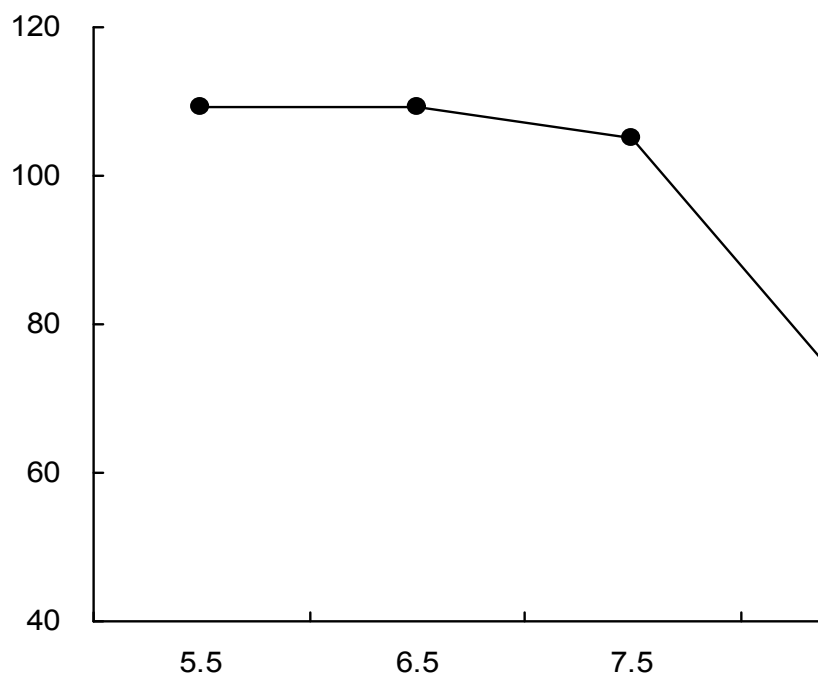

Fig. $5 \mathrm{~b}$. The $\mathrm{pH}$ stability of the protease.

The $\mathrm{pH}$ stability of the enzyme was determined by incubating the enzyme solution in different buffers for $30 \mathrm{~min}$ at $50^{\circ} \mathrm{C}$ and the residual activity was measured at $\mathrm{pH} 6.5$ and $50^{\circ} \mathrm{C}$. The protease activity before incubation was taken as $100 \%$.

isolated strain IB No. 11, the enzyme activity was measured in the presence of several different protease inhibitors.

As seen in Fig. 7a, the protease activity was remarkably inhibited by PMSF, a serine-protease specific inhibitor, exhibiting a dose-dependent response to this modifier at concentrations between 0.02 and $5.0 \mathrm{mM}$. On the other hand, the other inhibitors tested in this experiment did not significantly lower the protease activity but by the chelating agent EDTA, the enzyme activity was 


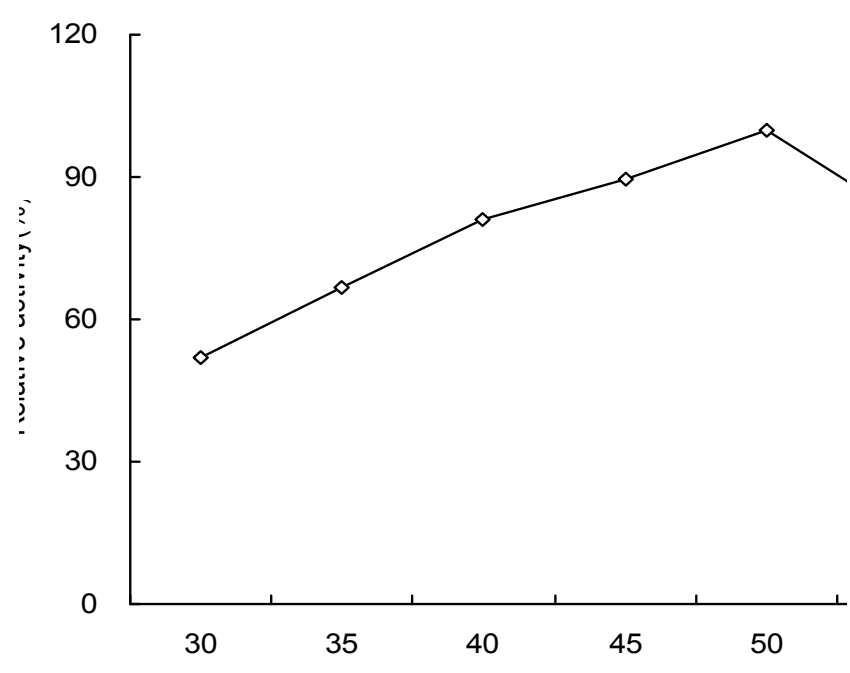

Fig. 6a. Effect of temperature on the protease activity. The activity of the protease determined at $50^{\circ} \mathrm{C}$ and $\mathrm{pH}$ 6.5 was taken as $100 \%$.

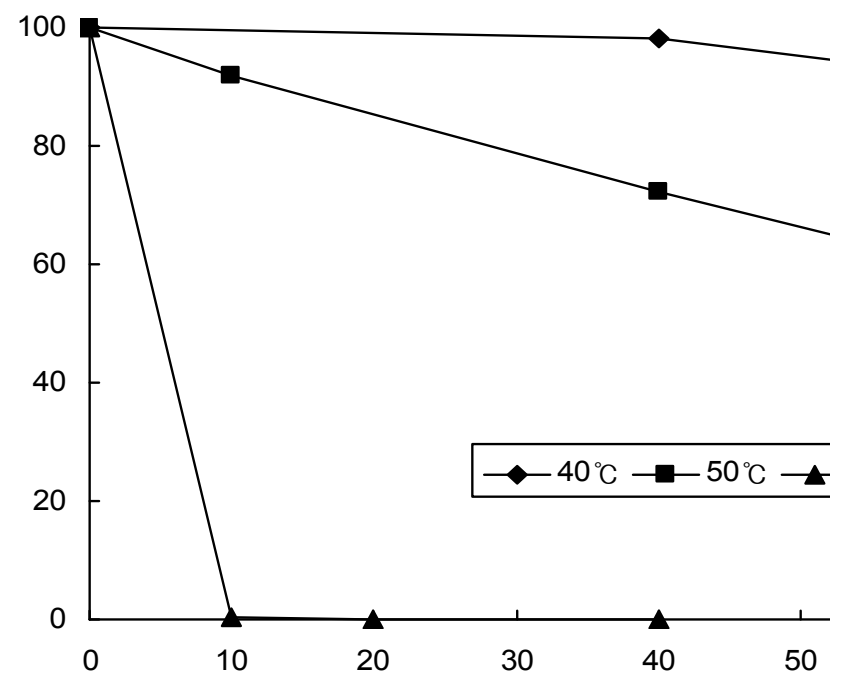

Fig. 6b. Effect of temperature on the enzyme stability.

The temperature stability was determined by incubating the enzyme at temperatures from 40 to 60 ${ }^{\circ} \mathrm{C}$ for $15 \mathrm{~min}$. The original activity before preincubation was taken as $100 \%$.

shown to be slightly inhibited, with about $29 \%$ of its original activity being lost at the concentration of $5 \mathrm{mM}$. These findings implied that some metal ion(s) plays an important role in the catalytic activity of the protease.

In addition, pepstatin, the target amino acid of which is aspartic acid had also no significant influence on the protease activity as shown in the inset of Fig. 7a.

Taken together, these results definitely indicated that the protease of the strain IB No. 11 is a member of serine proteases.

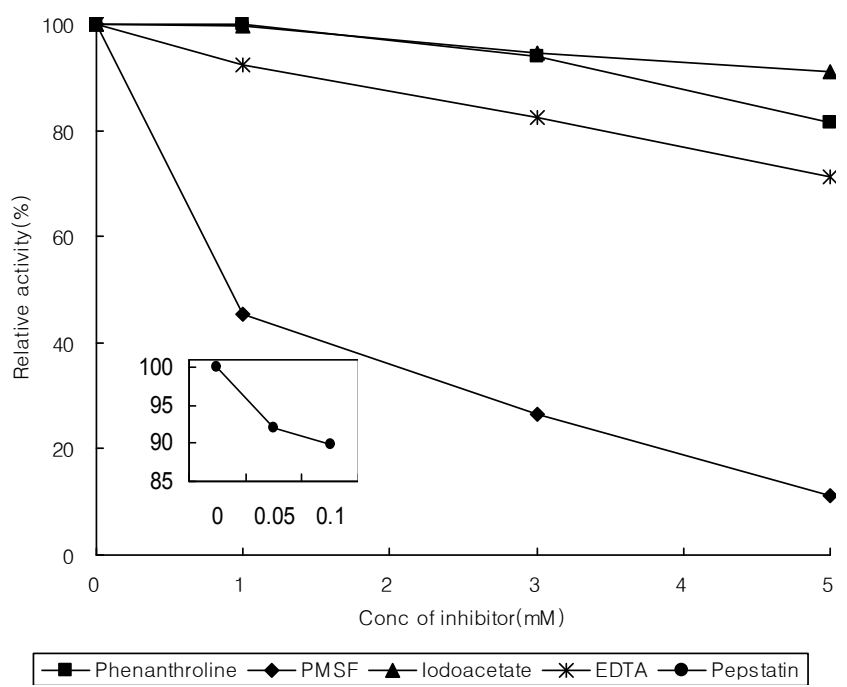

Fig. 7a. Effect of inhibitors on the protease activity.

The protease activity determined in the absence of inhibitors under the standard assay conditions was taken as $100 \%$.

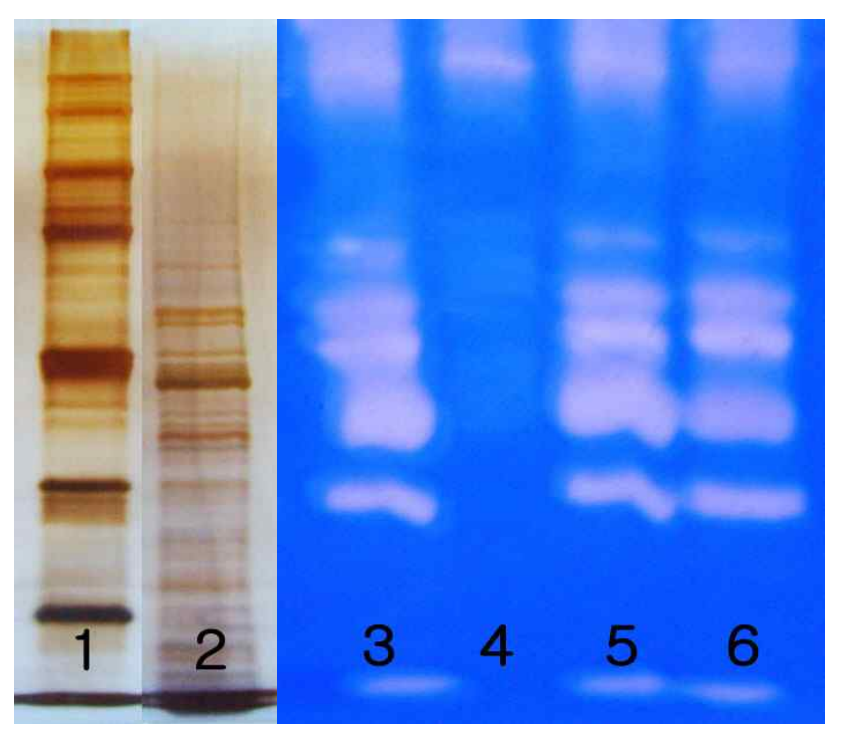

Fig. 7b. Zymogram analysis of inhibition of the protease activity.

Lanes 1\&2 : SDS-PAGE stained with silver salts; 1 , molecular markers ; 2 , crude protease preparation. Lanes 3,4,5, and 6: Zymogram analysis; 3, no inhibitor; 4, PMSF, 5, iodoacetate, 6 , penanthroline.

This was further illustrated by zymographic analysis of the protease, showing no recognizable clear zone on the lane of the SDS-PAGE contained PMSF (Fig. 7b).

Next, the influence of some metal ions, at the concentrations of $1 \mathrm{mM}$ and $5 \mathrm{mM}$, on the protease activity was investigated at $\mathrm{pH}$ 6.5 and $50^{\circ} \mathrm{C}$ by addition of the respective metallic ion to the enzymic reaction mixture (Table 3 ). 
Table 3. Effect of various metal ions on the protease activity

\begin{tabular}{ccc}
\hline \multirow{2}{*}{ Metal ion } & \multicolumn{2}{c}{ Relative activity (\%) at the conc. of: } \\
\cline { 2 - 3 } & $1 \mathrm{mM}$ & $5 \mathrm{mM}$ \\
\hline \hline $\mathrm{Cu}^{2+}$ & 54.1 & 80.9 \\
$\mathrm{Fe}^{2+}$ & 71.4 & 66.9 \\
$\mathrm{Mg}^{2+}$ & 98.6 & 101.3 \\
$\mathrm{Mn}^{2+}$ & 104.7 & 154.0 \\
$\mathrm{Zn}^{2+}$ & 114.4 & 96.4 \\
$\mathrm{Ca}^{2+}$ & 110.2 & 140.7 \\
\hline
\end{tabular}

The protease activity was determined by incubating the enzyme in the presence of each metal ion for $10 \mathrm{~min}$ at $\mathrm{pH} 6.5$ and $50^{\circ} \mathrm{C}$.

The addition of $\mathrm{Mn}^{2+}$ and $\mathrm{Ca}^{2+}$ at the concentration of $5 \mathrm{mM}$ enhanced the protease activity by 54.9 and $40.7 \%$, respectively compared to the control.

Particularly, $\mathrm{Ca}^{2+}$ exhibited an increasing activity up to $15 \mathrm{mM}$ but with $\mathrm{Mn}^{2+}$, no further enhancement was evident beyond 5.0 $\mathrm{mM}$ (Data shown). $\mathrm{Ca}^{2+}$ was reported to protect many proteases, especially serine-proteases against thermal denaturation by maintaining the active conformation of the enzyme molecule at high temperatures $(1,16$, and 23$)$.

However, the strain IB No. 11 protease was observed not to be protected from thermal inactivation in the presence of $\mathrm{Ca}^{2+}$ at the concentrations examined in this experiment although the metal ion greatly enhanced the enzyme activity as described above.

In contrast, $\mathrm{Cu}^{2+}, \mathrm{Fe}^{2+}$, and $\mathrm{Zn}^{2+}$ were shown to inhibit the enzyme activity.

\section{Isolation of protease hyper-producing mutants}

A combination of UV irradiation and NTG mutagenesis, which was reported to be more effective than either procedure alone, was used to isolate mutants of the strain IB No. 11 capable of hyper-producing protease, and to develop with the resulting mutant strain a highly efficient fermentation process for mass-production of the protease $(4,8)$.

After UV irradiation, protease production by the selected mutant strains that had shown larger clear zones on the selective plates supplemented with a high concentration of nisin $(0.15$ $\mathrm{mg} / \mathrm{ml}$ ) was subsequently assessed in shake flask cultures.

A mutant strain designated as IB No. 11-3 was selected on the
Table 4. Protease production by the mutant strains of the isolate IB No. 11

\begin{tabular}{lcccc}
\hline & $\begin{array}{c}\text { Biomass } \\
(\mathrm{OD} \text { at } 600 \mathrm{~nm})\end{array}$ & $\begin{array}{c}\text { Activity } \\
(\mathrm{U} / \mathrm{ml})\end{array}$ & $\begin{array}{c}\text { Specific activity } \\
(\mathrm{U} / \mathrm{mg})\end{array}$ \\
\hline \hline IB No 11 & 0.25 & 0.35 & 2.76 \\
IB No 11 & 3 & 0.14 & 0.75 & 5.92 \\
IB No 11 4 & 0.19 & 1.05 & 6.25
\end{tabular}

Samples of the culture supernatant from the 30 h-old culture at 4 $0^{\circ} \mathrm{C}$ in the protease production medium were used for the protease assay.

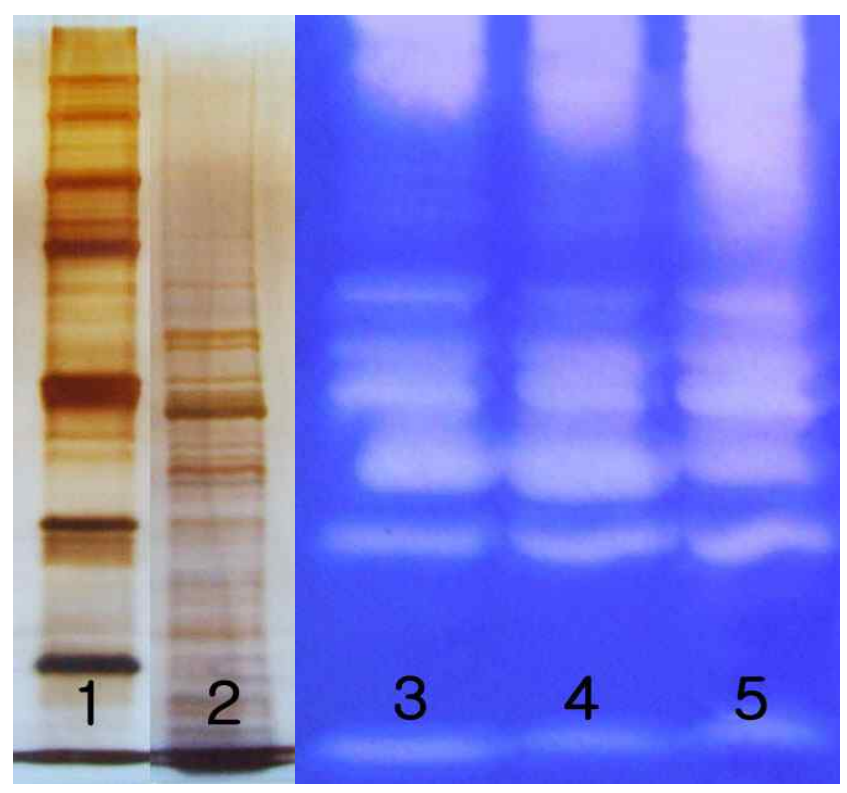

Fig. 8. Zymogram analysis of the protease produced by the parent and mutant strains.

Lanes 1\&2: SDS-PAGE stained with silver salts; 1, molecular markers; 2 , crude enzyme solution.

Lanes 3, 4, and 5: Zymogram analysis; 3, enzyme solution from IB No. 11; 4, enzyme solution from IB No. 11-3; 5, enzyme solution from IB No. 11-4.

basis of increased resistance to the peptide antibiotic nisin, and the resulting enhanced protease production.

Strain IB No. 11-3 revealed approximately 1.14-fold increase in protease production over the parent strain IB No11 when grown in the basal medium for $30 \mathrm{~h}$ at $40^{\circ} \mathrm{C}$.

Subsequently, the mutant IB No. 11-3 was treated with NTG according to the protocol described in Materials and Methods. Among the positive colonies on the selective agar plates supplemented with $0.2 \mathrm{mg} / \mathrm{ml}$ nisin, 6 colonies showed further improvement in protease production judged by the size of halos 
formed around their colony.

Using shake flask cultures, the protease production of these purified mutant strains was evaluated three times. The finally selected mutant IB No. 11-4 produced the highest protease activity (1.13 units $/ \mathrm{ml})$ estimated to be approximately 3.23 -fold higher than that for the strain IB No. 11 (Table 4).

The protease production profiles of the mutant strains isolated in this experiment were also proved by the activity bands on gelatin zymography (Fig. 8).

Intriguingly, the crude enzyme preparation showed at least 6 activity bands on the gelatin zymogram, suggesting that presumably 6 proteases were produced by the isolate.

And, the protease(s) of larger molecular weight migrating at about $100 \mathrm{kDa}$ showed remarkably enhanced proteolytic activity as seen in the figure. The molecular basis of this great increase in the protease activity remains to be further studied.

\section{REFERENCES}

1. Anisa, Haddar, Bougatef, A., Agrebi, R., Kamoun, A. S. and Nasri, M. 2009. A novel surfactant-stable alkaline serineprotease from a newly isolated Bacillus mojavensis A21. Process Biochemistry 4429-35.

2. Bascaran, V., Hardisson, C. and Brana, A. F. 1990. Regulation of extracellular protease production in Streptomyces clavuligerus. Appl. Microbiol. Biotechnol. 34:208-213.

3. Bradford, M. M. 1976. A rapid and sensitive method for the quantitation of microgram quantities of protein utilizing the principle of protein-dye binding. Anal. Biochem. 72:248-258.

4. Chandra, M., Kalra, A., Sangwan, N. S., Guarv, S., Darokar, M. and Sangwan, R. 2009. Development of a mutant of Trichoderma citrinoviride for enhanced production cellualases. Biores. Technol. 100:1659-1662.

5. Cupp-Enyard, C. 2008. Sigma's non-specific protease activity assay-Casein as a substrate. J. of visualized experiments JoVE 19:1-2.

6. Donaghy, J. A. and Mckay, A. M. 1993. Production and properties of an alkaline protease by Aureobasidium pullulans. J. Appl. Bacteriol. 74:000-000.

7. Ferrero, M. A., Cartro, G. R., Abate, C. M., Baigori, M. D. and Sineriz, F. 1996. Thermostable alkaline protease of Bacillus licheniformis MIR29: isolation, production, and characterization. Appl. Microbiol. Biotechnol. 45:327-332.
8. Fang, W., Shinichi, Y., Inoue, H. and Sawayama, S. 2009. Strain improvemrnt of Acremonium cellulolyticus for cellulose production by mutation. J. Biosci. and Bioeng. 107:256-261.

9. Giesecke, U. E., Bierbaum, G., Rudde, H., Spohn, U. and Wandrey, C. 1991. Production of alkaline protease by with Bacillus licheniformis in a controlled fed-batch process. Appl. Microbiol. Biotechnol. 35:720-724.

10. Gupta, R., Beg, Q. K. and Lorenz, P. 2002. Bacterial alkaline proteases: molecular approaches and industrial applications. Appl. Microbiol. Biotechnol. 59:15-32.

11. Garrity, G. Bergey's manual of systemic bacteriology. 2005. Williams and Wilkins Company, Baltimore.

12. Hamlon G. W., Hodges, N. A. and Russel, A. D. 1982. The influence of glucose, ammonium, and magnesium availability on the production of protease and bacitracin by Bacillus licheniformis. J. Gen. Microbiol. 128:845-851.

13. Kole, M. M., Draper, I. and Gerson, D. F. 1988. Protease production by Bacillus subtilis in oxygen-controlled, glucose fed-batch fermentations. Appl. Microbiol. Biotechnol. 28: 404408.

14. Kole, M. M., Draper, I. and Gerson, D. F. 1988. Production of protease by Bacillus subtilis using simultaneous control of glucose and ammonium concentrations. J. Chem. Technol. Biotechnol. 41:197-206.

15. Moon, S. H. and Parulekar, S. J. 1991. A parametric study of protease production in batch and fed-batch cultures of Bacillus firmus. Biotechnol. Bioeng. 37:467-483.

16. Nisha, P., Singh, S. P. and Garg, S. K. 1994. Cation-induced thermal stability of an alkaline protease from a Bacillus sp. Biores. Technol. 50:209-211.

17. Qasim, K. B., Saxena, R. K. and Gupta, R. 2002. Derepression and subsequent induction of protease synthesis by Bacillus mojavensis under fed-batch operations. Process Biochemistry 37:1103-1109.

18. Ramesh, S., Rajesh, M. and Mathivanan, N. 2009. Characterization of a thermostable alkalilne protease produced by marine Streptomyces fungicidicus MML 1614. Bioprocess Biosyst. Eng. Published online.

19. Saeki, K., Ozaki, K., Kobayashi, T. T. and Ito, S. 2007. Detergent alkaline proteases: enzymatic properties, genes, and crystal structures. J. Biosci. Bioeng. 103:501-508.

20. Stackebrandt, E. and Goebel, B. M. 1994. A place for DNADNA reassociation and $16 \mathrm{~S}$ rRNA sequence analysis in the 
present species definition in bacteriology. Int. J. Syst. Bacteriol. 44:846-849.

21. Sissons, J., Alsam, S., Graham, G., Lightfoot, M., Jarroll, E. L. and Khan, N. A. 2006. Identification and properties of proteases from an Acanthamoeba isolate capable of producing granulomatous encephalitis. BMC Microbiology. 6:6-42.

22. Sandeep, K., Vohra, R. M., Kapoor, M., Beg, Q. K. and Hoondal, G. S. 2001. Enhanced production and characterization of a highly thermostable alkaline proteae from Bacillus sp.
P-2. W. J. Microbiol. \& Biotechnol. 17:125-129.

23. Xue-Ming, T., Lakay, F. M., Shen, W., Shao, W. L., Fang, H. Y., Prior, B. A., Wang, Z. X. and Zhuge, J. 2004. Purification and characterization of an alkaline protease used in tannery industry from Bacillus licheniformis. Biotech. Letts. 26:14211424.

(Received August 20, 2009; Revised December 18, 2009; Accepted December 18, 2009) 